\title{
PERBEDAAN TINGKAT KETEPATAN FREE THROW ANTARA BOLABASKET UKURAN 7 DAN 5 PADA SISWA PUTRI KELAS XI SMA NEGERI 2 MUARA ENIM
}

\author{
Amalia Barikah
}

\author{
Universitas Islam Kalimantan Muhammad Arsyad Al Banjari Banjarmasin \\ amaliabarikah29@gmail.com
}

\begin{abstract}
ABSTRAK
Penelitian ini bertujuan untuk mengetahui perbedaan ketepatan free throw pada permainan bolabasket dengan menggunakan bolabasket ukuran 7 dengan bolabasket ukuran 5 pada siswa putri kelas XI SMA Negeri 2 Muara Enim.

Populasi dari penelitian ini adalah seluruh siswa putri kelas XI SMA Negeri 2 Muara Enim, dengan jumlah 129 siswa. Adapun sampel yang digunakan sebanyak 40 responden yang diambil dengan cara proportional random sampling. Pengambilan data menggunakan metode survey, dengan teknik tes dan pengukuran. Instrumen yang digunakan berupa tes shooting atau memasukkan bola ke ring dari area free throw sebanyak 10 kali.

Hasil uji t diperoleh t hitung sebesar -3,053 lebih besar dari t tabel sebesar 1,685. Ini berarti ada perbedaan signifikan ketepatan free throw pada permainan bolabasket dengan menggunakan bolabasket ukuran 7 dengan bolabasket ukuran 5 pada siswa putri kelas XI SMA Negeri 2 Muara Enim. Free throw menggunakan bola bolabasket ukuran 5 lebih tepat (baik) daripada menggunakan bola bolabasket ukuran 7, dengan besarnya rerata 3,78 dan 3,05 .
\end{abstract}

Kata Kunci : Bolabasket, Free Throw, Ketepatan

\begin{abstract}
This study aims to determine the relationship of free throw in the basketball was using basketball between seven sizes with five sizes of women students at senior high school 2 Muara Enim State.

The population of this research is the entire women students at senior high school 2 Muara Enim State exspecially eleven class students were 129 students. For the samples used as many as 40 respondents taken by proportional random sampling. The retrieval method is survey, technic in the research is test and measurement. The instrument is shooting tests or insert the ball into the hoop from free throw area of as much as ten times. $T$ test results obtained t count registration-3.053 greater than t table of 1.685. that means have significant difference accuracy of free throw in the basketball was using the ball seven sizes with five sizes of women students at senior high school 2 Muara Enim State. And Free throw was using the ball with five sizes is more be better than seven sizes which the magnitude of the average is 3.78 and 3.05 .
\end{abstract}

Keywords: Basketball, Free Throw, Accuracy 


\section{PENDAHULUAN}

Pendidikan jasmani merupakan salah satu pembelajaran yang dipelajari dan bersifat praktek atau melakukan kegiatan secara langsung di lapangan. Berkaitan dengan hal tersebut, dalam pembelajaran pendidikan jasmani memerlukan adanya media atau alat (sarana dan prasarana) yang mampu mendorong kelancaran selama proses pembelajaran berlangsung, sehingga tujuan pembelajaran pendidikan jasmani tercapai. Mata pelajaran pendidikan jasmani terdiri dari cabang atletik, senam, beladiri, dan permainan-permainan yang meliputi bola kecil dan bola besar. Siswa sangat senang mengikuti pelajaran pendidikan jasmani khususnya dalam bentuk permainan-permainan bola besar, dikarenakan permainan bola besar umumnya mudah dimainkan dan sangat familiar di masyarakat. Contoh permainan bola besar yaitu sepakbola, bolavoli, bolakeranjang, bolatangan, dan bolabasket.

Permainan bolabasket merupakan salah satu permainan bola besar yang akhir-akhir ini banyak diminati para siswa SMA. Federation Internationale De Basketball (FIBA) central board (2014:5) Permainan bolabasket ini diciptakan oleh seorang berkewarganegaraan Amerika Serikat pada tahun 1891 yang bernama James A. Naismith. Ide untuk menciptakan sebuah olahraga baru ini disebabkan oleh kejenuhan para anggota perkumpulan olahraga yang bernama Young Men's Christian Asociation (Y.M.C.A) yang semakin hari semakin sedikit jumlahnya dan mengalami kebosanan akan olahraga senam sebagai alternatif olahraga di musim dingin.

Bolabasket merupakan olahraga permainan bola besar dan dimainkan oleh dua regu yang dimasingmasing regu terdiri dari 5 orang pemain, tujuannya adalah untuk mencari nilai atau angka sebanyak banyaknya dengan cara memasukkan bola ke basket lawan dan mencegah lawan untuk mendapatkan nilai (Muhajir, 2007: 11). Bolabasket adalah salah satu jenis olahraga yang dimainkan dengan tangan. Permainan bolabasket merupakan salah satu cabang olahraga yang dikembangkan di Indonesia, baik melalui pendidikan jasmani di sekolah maupun oraganisasi lainya yang di bawah naungan PERBASI (Persatuan Bolabasket Seluruh Indonesia), hal tersebut merupakan pengembangan dalam rangka untuk menunjang tercapainya prestasi yang terbaik di tingkat nasional dan internasional. Pembelajaran dasar bermain bolabasket biasanya terdapat dalam kurikulum pembelajaran, dan dengan melihat serta mempertimbangkan minat siswa yang banyak menggemari permainan ini, maka pembelajaran bolabasket sering dijadikan sebagai kegiatan jam pelajaran tambahan (ekstrakurikuler).

Dalam permainan bolabasket, suatu kemenangan akan dicapai apabila suatu tim bisa memasukan bola ke dalam keranjang lawan sebanyak mungkin dan mampu menahan kemasukan bola lebih sedikit. Bolabasket mempunyai tiga teknik dasar yaitu lempar-tangkap, menembak, dan menggiring. Ketiga teknik ini tidak dapat dipisahkan satu sama dengan yang lain, meskipun ketiganya mempunyai arti yang berbeda. Dengan berkembangnya bolabasket yang semakin pesat dan didukung oleh kemampuan menembak secara cepat dan cermat dalam pertandingan, harapan untuk mencapai suatu kemenangan dapat terwujud. Salah satu teknik dalam bolabasket untuk memperoleh angka adalah menembak dengan tembakan bebas yang dilakukan di daerah hukuman. Tembakan bebas atau lebih dikenal dengan free throw merupakan salah satu teknik untuk mendapatkan angka yang dilakukan oleh seorang penembak yang memperoleh hadiah karena lawan melakukan kesalahan. Keterampilan dasar menembak merupakan kemampuan mendasar dalam bermain bolabasket, yang dilakukan dengan gerakan sederhana dan efektif untuk mencapai tujuan.

Teknik free throw dalam bolabasket mempunyai peran yang sangat penting, karena dalam melakukan free throw bukan hanya dibutuhkan teknik yang baik tetapi juga ketenangan dari penembak untuk mendapatkan hasil dari free throw. Meskipun dalam perolehan angka free throw hanya diberi nilai satu angka setiap bola masuk, tetapi bagi penembak yang berhasil membuat angka dari free throw akan semakin membuat percaya diri dan mampu mengulanginya lagi. Bahkan dalam suatu pertandingan yang ketat perolehan angkanya, satu tembakan free thow yang masuk di akhir-akhir laga dapat memenangkan salah satu tim dalam pertandingan.

Free throw yang dilakukan oleh pemain sesuai dengan kebiasaannya, ada yang melakukan dengan teknik satu tangan dan teknik dua tangan. Pada dasarnya seperti yang telah dijelaskan di atas free throw merupakan teknik yang memerlukan koordinasi tangan, kaki, mata yang baik dan teknik tembakan ini memerlukan tingkat konsentrasi yang tinggi. Penguasaan teknik free throw yang baik merupakan salah hal yang menentukan kemenangan, karena penguasaan teknik free throw yang baik dan benar, kemungkinan memasukan bola ke dalam keranjang yang merupakan tujuan dari permainan bolabasket itu sendiri akan semakin besar.

Pemahaman konsep yang beragam dalam penguasaan teknik free throw yang dilakukan oleh siswa SMA dan juga pengaruh perbedaan fisik siswa, khususnya siswa putri di Indonesia (SMA Negeri 2 Muara Enim) yang rata-rata lebih kecil dari pada fisik siswa putri negara asal ditemukannya bolabasket yaitu Amerika Serikat, mengakibatkan banyaknya kegagalan saat melakukan free throw, yaitu bola banyak yang tidak sampai ke ring basket. Kegagalan saat melakukan free throw tersebut disebabkan oleh berbagai macam faktor, yang salah satunya bisa ditinjau dari sudut pandang biomekanika. Dalam biomekanika olahraga mempunyai beberapa tujuan, diantaranya mengetahui gerakan yang efektif dan efisien dalam suatu rangkaian gerak dan mengetahui faktor apa yang mempegaruhi keberhasilan (penguasaan bola, keringanan berat dan ukuran bola). Melihat 
berbagai permasalahan tersebut, timbul keinginan peneliti untuk mengadakan penelitian tentang salah satu hal yang bisa mempengaruhi hasil saat siswa SMA putri dalam melakukan free throw, dengan judul "Perbedaan Tingkat Ketepatan Free throw antara Bolabasket Ukuran 7 dan 5 Pada Siswa Putri Kelas XI SMA Negeri 2 Muara Enim". Penelitian ini dilakukan dengan mengambil sampel di SMA Negeri 2 Muara Enim, dengan harapan para pendidik mengetahui dan menggunakan bolabasket ukuran yang tepat saat mengajar siswanya, sehingga peserta didik yang mengikuti pembelajaran pendidikan jasmani khususnya materi bolabasket akan termotivasi mengikuti proses pembelajaran dan mampu meningkatkan prestasi dalam shooting free throw (bola banyak yang masuk ke keranjang basket). Dalam penelitian ini, alat yang digunakan adalah bolabasket dengan ukuran 7 dan 5 sebagai pembanding berapa banyak bola yang berhasil masuk dalam keranjang saat melakukan free throw oleh siswa putri kelas XI di SMA Negeri 2 Muara Enim.

TINJAUAN TEORITIS

Permainan bolabasket adalah permainan yang menggunakan bola besar, yang dimainkan dengan tangan dan bertujuan memasukkan bola sebanyak mungkin ke (keranjang) lawan serta menahan lawan agar jarang memasukkan bolabasket (keranjang) sendiri (Dedy Sumiyarsono, 2002:1). Bolabasket merupakan olahraga permainan bola besar dan dimainkan oleh dua regu yang dimasing-masing regu terdiri dari 5 orang pemain, tujuannya adalah untuk mencari nilai atau angka sebanyak banyaknya dengan cara memasukkan bola ke basket lawan dan mencegah lawan untuk mendapatkan nilai (Muhajir, 2007: 11).

Hall Wisell (2004:1-3) Mekanika gerakan yang harus di perhatikan oleh para atlet dan siswa saat melakukan shooting free throw yaitu :

1.Pandangan

Pandangan mata dipusatkan pada keranjang basket dan ditujukan hanya pada sisi muka lingkaran. Teknik shooting pandangan tertuju pada puncak dekat sudut kotak papan keranjang basket. Pandangan mata tetap terfokus sampai bola mencapai sasaran dan pandangan mata mengikuti arah gerakan bola atau tangan penjaga

2.Keseimbangan

Keseimbangan yang baik akan memberikan tenaga dan kontrol irama tembakan. Kedua kaki sejajar bahu dan jari kaki diarahkan kedepan.

3.Posisi Tangan

Tangan yang digunakan untuk menembak ditempatkan tepat dibelakang bola sebagai penjaga keseimbangan (block and tuck) tangan cukup rapat, rileks dan jari-jari tangan terlentang secukupnya, jaga jarijari tangan penembak rileks, ibu jari tangan tidak terentang lebar (menghindarkan ketegangan pada tangan dan lengan atas).

Perlu diperhatikan saat melakukan free throw cara memegang bola, posisi siku, pergelangan tangan dan tubuh harus segaris dengan keranjang. Free throw memiliki posisi yang sama dengan set shoot. Penempatan berat badan pada kaki tumpuan adalah sangat penting supaya keseimbangan tubuh benar-benar kokoh. Sesaat sebelum melepas bola, pemain disarankan menghentikan pergerakannya sebentar untuk fokus pada keranjang. Tarik nafas panjang yang dalam saat akan melakukan free throw untuk membantu konsentrasi pemain. Adapun langkah-langkah free throw adalah :

1. Berdiri di tengah garis dalam lingkaran, jangan sampai sepatu menginjak garis. Kaki direntangkan selebar bahu.

2. Dribble bola beberapa kali supaya tidak tegang dan sedikit rileks. Lutut ditekuk sedikit sampai otot paha mempunyai kekuatan untuk melakukan shooting. Kaki kanan seharusnya sedikit lebih di depan.

3.Fokus ke arah sasaran. Bahu dan badan menghadap lurus ke keranjang basket.

4.Gunakan kedua tangan untuk memegang bola, tetapi sebenarnya hanya satu tangan yang akan digunakan mendorong bola. Jangan melakukan shooting dengan dua tangan.

5.Tangan kanan adalah landasan dan seharusnya berada di bawah bola dengan pergelangan tangan mengarah ke belakang. Siku lengan ditekuk kira-kira 900, seperti huruf "L" terbalik, dan berada di bawah bola (bukan di sisi luar bola).

6.Jika bahu dan kaki menghadap lurus ke keranjang basket, tempatkan bola di sebelah kanan wajah, sedikit di depan dari bahu.

7. Konsentrasi pada titik tersebut, dan jangan melihat bola.

8.Gunakan bahu sebagai engsel. Lengan kanan menjulur ke depan mengarah ke keranjang basket (dengan siku tetap di dalam), siku lengan diluruskan, kemudian bola dilepaskan dengan bantuan gerakan pergelangan tangan dan ujung jari.

9.Jari-jari mengarah ke keranjang basket, dan pergelangan tangan ditekuk ke depan menyerupai leher angsa.

Free throw (Muhammad Danu Prabowo, 2016:23) 
Pawel Lenik, Tomasz Krzeszowski, Krzysztof Przednowek dan Justyna Lenik (2015:6) metode deteksi dan pelacakan bola selama free throw basket adalah proses pelatihan sebagai alat untuk meningkatkan kinerja dari lemparan bebas. Metode ini akan dapat memonitor lintasan bola yang akan membantu untuk meningkatkan kebiasaan motorik. Akibatnya melempar pemain akan sejalan dengan waktu akan benar dan dengan lintasan yang optimal.

Bola merupakan alat atau sarana dalam pembelajaran pendidikan jasmani. Menurut Agus S. Suryobroto (2004 : 4), alat atau sarana adalah segala sesuatu yang diperlukan dalam pembelajaran pendidikan jasmani, mudah dipindah bahkan dibawa oleh pelakunya atau siswa. Salah satu contoh dari alat atau sarana adalah bola. Dengan adanya bola sebagai sarana pembelajaran pendidikan jasmani diharapkan tujuan pembelajaran akan tercapai secara optimal. Bola adalah benda yang berbentuk bulat terbuat dari kulit atau bahan yang lain yang digunakan sebagai alat bermain dalam suatu olahraga. Dalam Kamus Besar Bahasa Indonesia (2002:1089), kata standar berarti ukuran tertentu yang dipakai sebagai patokan dan sesuatu yang dianggap memiliki nilai tetap (baku).

Bola yang dapat dipakai dalam permainan ini harus memiliki syarat sebagai berikut : bola terbuat dari kulit, karet atau bahan sintesis lainnya yang tidak membahayakan bila digunakan. Bola bolabasket ukuran 7 (keliling lingkaran 749-780 mm, berat 567-650 gram) untuk putra, bola bolabasket ukuran 6 (keliling lingkaran 724-737 mm, berat 510-567 gram) untuk putri dan bola bolabasket ukuran 5 (keliling lingkaran $695 \mathrm{~mm}$, berat 490 gram) untuk anak siswa SD.

\section{METODE}

Dalam penelitian ini penulis menggunakan metode survei dengan teknik tes. Tes yang digunakan yaitu menembak ke arah sasaran memasukkan bola ke dalam keranjang basket dari area free throw sebanyak 10 kali tembakan menggunakan bola basket ukuran 7 dan 5 untuk memperoleh skor. Setiap siswa memiliki 1 kali kesempatan 10 kali tembakan free throw untuk memasukkan bola ke keranjang basket (Agus- Amin Setiono, 2003). Populasi dari penelitian ini adalah seluruh siswa putri kelas XI SMA Negeri 2 Muara Enim, dengan jumlah 129 siswa. Adapun sampel yang digunakan sebanyak 40 responden yang diambil dengan cara proportional random sampling. Pengambilan data menggunakan metode survey, dengan teknik tes dan pengukuran. Instrumen yang digunakan berupa tes shooting atau memasukkan bola ke ring dari area free throwsebanyak 10 kali menurut Agus- Amin Setiono (2003). Teknik analisis data menggunakan analisis uji t, melalui uji prasyarat normalitas, dan homogenitas.

\section{HASIL DAN PEMBAHASAN}

Hasil penelitian dan pengujian hipotesis menunjukkan bahwa ada perbedaan yang signifikan ketepatan free throw pada permainan bolabasket dengan menggunakan bolabasket ukuran 7 dengan bola bolabasket ukuran 5 pada siswa putri kelas XI SMA Negeri 2 Muara Enim, yang ditunjukkan dengan $t$ hitung lebih besar dari $t$ tabel. Ternyata hasil ketepatan free throw menggunakan bolabasket ukuran 5 lebih baik daripada menggunakan bolabasket ukuran 7. Perbedaan itu juga ditunjukkan oleh besarnya rerata dari kedua kelompok yang berbeda, bahwa rerata ketepatan free throw menggunakan bolabasket ukuran 5 lebih efektif daripada rerata ketepatan free throw menggunakan bolabasket ukuran 7, yaitu sebesar 3,78 dan 3,05.

Pembelajaran bolabasket pada siswa putri kelas XI SMA seharusnya tidak menggunakan bolabasket ukuran 7 melainkan menggunakan bolabasket ukuran 5, dikarenakan bila free throw menggunakan bolabasket ukuran 7 banyak siswa yang gagal, sehingga banyak bola hasil tembakan tidak sampai ke ring, ini semua dipengaruhi jarak tembakan free throw dengan ring basket cukup jauh dan ukuran bola yang kelilingnya besar dan beratnya juga 700 gram, maka wajar saja jika siswa putri XI SMA Negeri 2 Muara Enim kurang berhasil melakukan free throw.

Ketepatan free throw dikatakan efektif apabila bola dapat masuk ke dalam ring basket. Karena free throw dengan bolabasket ukuran 7 banyak siswa putri yang kurang berhasil (tembakan bola banyak yang tidak sampai ke ring), sehingga perlu kiranya menggunakan bolabasket ukuran 5 dari pada bolabasket ukuran 7 . Dikarenakan bolabasket ukuran 5 lebih kecil dan ringan sehingga siswa putri lebih mudah mengarahkan sasaran tembakan free throw dan akhirnya hasil tembakan free throw lebih banyak yang masuk ke dalam ring. Dalam hal ini dapat disimpulkan bahwa siswa putri tidak kuat melakukan free throw menggunakan bolabasket ukuran 7 , dan demi kelancaran pembelajaran bolabasket, yaitu materi lemparan bebas sebaiknya guru pendidikan jasmani memodifikasi bolabasket ukuran 7 dengan mengganti bolabasket ukuran 5 agar siswa putri mampu melakukan free throw dengan baik.

Memperhatikan nilai rerata dari kedua hasil ketepatan free throw nilai rerata ketepatan free throw menggunakan bolabasket ukuran 5 hasilnya lebih baik daripada menggunakan bolabasket ukuran 7 . Namun jika kita perhatikan nilai standar deviasinya, bawasannya standar deviasi untuk ketepatan free throw menggunakan bolabasket ukuran 7 lebih kecil dari pada bolabasket ukuran 5, yaitu 1,57 dan 1,90. hal ini menunjukkan bahwa 
ketepatan free throw menggunakan bolabasket ukuran 7 lebih stabil dari pada ketepatan free throw menggunakan bola bolabasket ukuran 5 . kestabilan ini dikarenakan dalam pembelajaran lebih sering menggunakan bola bolabasket ukuran 7 sehingga sudah lebih terbiasa, hanya saja karena beban yang berat, sehingga banyak siswa putri yang lemparannya tidak sampai ke ring atau arahnya tidak mengarah.

\section{PENUTUP}

Berdasarkan hasil penelitian yang telah diperoleh dengan analisis dan pengujian hipotesis, maka dapat ditarik kesimpulan;

1.Ada perbedaan yang signifikan ketepatan free throw pada permainan bolabasket dengan menggunakan bolabasket ukuran 7 dengan bolabasket ukuran 5 pada siswa putri kelas XI SMA Negeri 2 Muara Enim.

2.Free throw menggunakan bolabasket ukuran 5 mempunyai ketepatan yang lebih baik dari pada menggunakan bolabasket ukuran 7.

SARAN

Dengan mengacu pada hasil penelitian dan keterbatasan-keterbatasan dalam penelitian, peniliti menyarankan:

1.Perlu diadakan penelitian lanjut dengan menambah variabel lain.

2.Dalam penelitian lanjut sebaiknya dengan sampel yang lebih banyak.

3.Menyediakan alat untuk mengukur berat dan tekanan bola yang akan digunakan untuk tes.

4.Bagi guru penjas, sebaiknya dalam mengajarkan lemparan bebas pada siswa putri menggunakan bolabasket ukuran 5, karena beratnya lebih ringan, sehingga akan banyak siswa yang berhasil melakukan lemparan bebas.

\section{REFERENSI}

Agus Amin Sulistiono. (2003). Penyusun Tes Keterampilan Bermain Bolabasket Usia Yunior. Tesis. PPS UNY.

Agus S Suryobroto. (2004). Sarana dan Prasarana Pendidikan Jasmani (Diktat). Yogyakarta: FIK UNY.

Danu, Muhammad Prabowo. (2015). "Tingkat Keterampilan Bermain Bola Basket Peserta Ekstrakurikuler Bola Basket Sma Negeri 1 Comal Kabupaten Pemalang Tahun Pelajaran 2016/2017’. Skripsi. UNY. Yogyakarta

Dedy Sumiyarsono. (2002). Keterlampilan Bola Basket. Yogyakarta: FIK UNY.

FIBA Central board Barcelona . (2014). Official Basketball Rules. Spain.

Lenik,Pawel. Et al. (2015). "The analysis of basketball free throw trajectory using PSO algorithm". Thesis. Poland.

Muhajir. (2007). Pendidikan Jasmani Olahraga dan Kesehatan. Jakarta: Erlangga.

Poerwodarminta. (2002). Kamus Besar Bahasa Indonesia edisi ke 3. Pusat Bahasa. Departemen Pendidikan Nasional. Jakarta: Balai Pustaka.

Wissel, H. (2004). BASKETBALL: Steps to Success. Human Kinetics, Champaign, IL. 2nd Edition. 